\title{
BATIK TOPO BANTUL: KONSISTEN DALAM PEMBUATAN KAIN BATIK TULIS DAN CAP
}

\author{
Anna Galuh Indreswari*)
}

\begin{abstract}
ABSTRAKSI
Penelitian ini mempunyai tujuan untuk mencari tahu mengenai usaha Batik Topo, terutama produk kain batik yang dihasilkannya. Produk kain batik yang dihasilkan meliputi motif dan proses pembuatannya. Bagaimana motif-motif batik yang dibuat oleh Batik Topo. Apa dan bagaimana proses pembuatan kain-kain batiknya selama ini. Tujuan penelitian ini sangatlah jelas untuk mengetahui lebih mendalam dan terperinci mengenai segala hal yang diproduksi oleh Batik Topo, dalam hal ini kaitannya dengan produk kain batiknya.

Penelitian mengenai usaha Batik Topo ini tentunya membutuhkan metode penelitian. Metode penelitian untuk memecahkan permasalahan dalam penelitian menggunakan beberapa metode dari disiplin ilmu yang berbeda. Penelitian ini menggunakan metode multidisiplin. Beberapa metode dari disiplin ilmu yang berbeda di antaranya, yaitu: estetika; sejarah; dan antropologi. Sedangkan metode pencarian data dilakukan dengan cara, yaitu: observasi; wawancara; dokumentasi; dan pustaka.

Penelitian ini menghasilkan kesimpulan bahwa usaha Batik Topo membuat kain batik dengan cara cap dan tulis, sehingga produknya disebut batik cap dan tulis. Pembuatan kain batik dengan cara demikian ikut mendukung pelestarian batik tradisional. Kain batik tradisional dengan pembuatan secara cap maupun ditulis menggunakan canting telah diakui sebagai world heritage.
\end{abstract}

Keywords: batik topo, batik, batik cap, batik tulis, world heritage.

\section{PENDAHULUAN}

Batik adalah kain bermotif dari Indonesia. Kain batik telah ada sejak jaman keraton-keraton di Jawa. Kain batik dipakai oleh seluruh lapisan masyarakat pada saat itu. Beberapa motif batik tertentu digunakan oleh lingkungan keraton, untuk menjaga tradisi dan wibawa keraton. Batik merupakan salah satu local genius yang menjadi ciri khas masyarakat.

\begin{abstract}
Sebagai local genius, batik mempunyai ciri-ciri kebudayaan yang dimiliki bersama oleh suatu masyarakat atau bangsa sebagai hasil pengalaman di masa lampau. Pengertian tersebut berarti merujuk pada kemampuan budaya setempat dalam menghadapi kebudayaan asing pada waktu kedua kebudayaan tersebut berhubungan (Timbul Haryono, 2008:80). Berarti, batik telah mengalami proses akulturasi, dalam
\end{abstract}

\footnotetext{
* Anna Galuh Indreswari (anagaluh@yahoo.com), Staf Pengajar Jurusan Kriya Fakultas seni Rupa Institut Seni Indonesia Yogyakarta
} 
hal ini bisa dilihat dalam motif-motif batik pesisiran.

Akulturasi terjadi apabila terdapat dua kebudayaan atau lebih yang berbeda sama sekali (asing dan asli) berpadu (Kodiran, 1998:87). Proses akulturasi pada kain batik banyak terjadi dalam motif batik pesisiran. Motif batik pesisiran lebih bersifat naturalis dan banyak dipengaruhi kebudayaan asing. Daerah batik pesisiran terdapat di Indramayu, Cirebon, Pekalongan, Madura dan Tuban. Akulturasi pada kain batik pesisiran menciptakan corak beraneka ragam dan warna-warna yang cerah.

Batik berarti seni membuat motif di atas kain dengan bahan perintang warna bernama lilin atau malam dan pewarnaannya menggunakan teknik pencelupan. Timbul Haryono menyatakan batik adalah suatu gambar berpola. Motif dan coraknya dibuat menggunakan teknik tutup celup (Timbul Haryono, 2008: 81). Secara etimologi, batik berasal dari kata berakhiran tik berasal dari kata menitik, artinya menetes. Menurut terminologinya, batik adalah gambar yang dihasilkan dengan menggunakan alat canting atau sejenisnya dengan bahan lilin atau malam sebagai penahan masuknya warna (A.N. Suyanto, 2002: 2).

\section{Usaha Batik TOPO Bantul}

Batik TOPO beralamatkan di Gesikan, Wijirejo, Pandak, Bantul. Daerah Pandak terletak di sisi sebelah selatan kota Yogyakarta. Perjalanan menuju rumah produksi batik TOPO relatif jauh dijangkau dari kota Yogyakarta. Pijenan Pandak terletak di sebelah barat daya pusat Kota Bantul. Daerahnya mendekati pelosok Kota Bantul, bahkan warga Bantul ada yang tidak mengetahui lokasi batik TOPO. Jalanan aspalnya halus berliku-liku melewati banyak tikungan dan persimpangan.

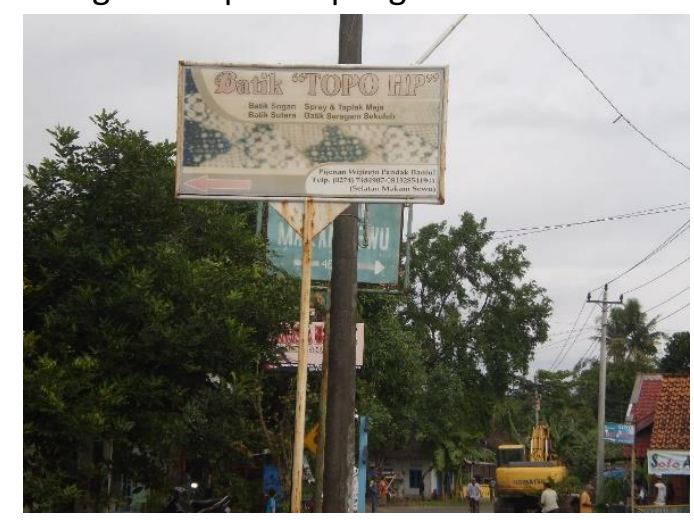

Gambar 1. Lokasi Batik TOPO Bantul.

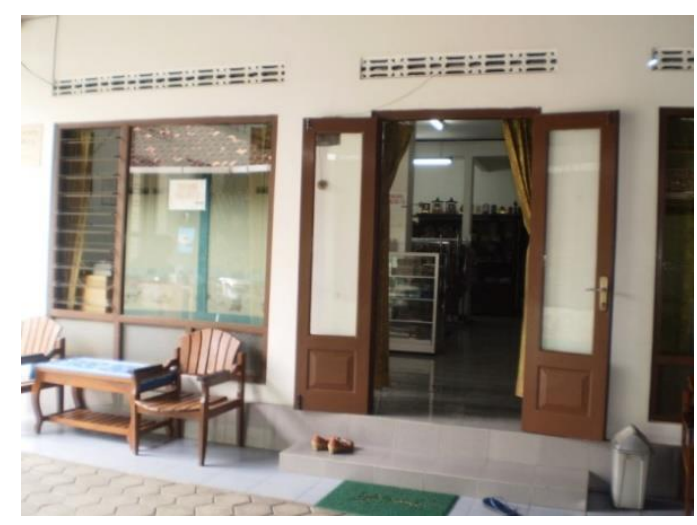

Gambar 2. Toko Batik TOPO tampak depan.

Batik TOPO merupakan usaha keluarga. Usaha penjualan batik ini dikelola oleh Topo HP, yang merupakan tokoh usaha batik di Bantul. Usaha batik TOPO adalah salah satu usaha kecil di Bantul yang tetap bisa eksis setelah kejadian gempa 27 Mei 2006. Sejarah berdirinya batik TOPO dimulai pada tahun 1973. Dahulu, Topo HP hanyalah buruh batik di Yogyakarta. Tahun 1973, pembatikan di Yogyakarta mengalami goncangan hebat sehingga berdampak pada pembubaran usaha batik. Topo HP akhirnya hijrah mencari pekerjaan ke Jakarta. Topo HP bekerja di sebuah industri batik yang bernama Usaha Batik Sidomukti.

Bekerja selama 6 tahun di Jakarta, dari tahun 1974- 1980, akhirnya Topo HP memutuskan pulang ke Yogyakarta. Usaha 
batik TOPO dibangun dengan modal kain mori 2 pis (2 kodi), yang dibatik cap dan diwarna sendiri. Produknya dijual di Pasar Gedhe (Beringharjo) dan terjual habis. Usaha batik Topo semakin berkembang dan mempunyai 2 karyawan pada tahun 1981.

Batik berjaya pada tahun 19851987. Tahun ini dapat dikatakan batik mengalami booming. Tetapi, krisis moneter (krismon) yang terjadi pada tahun 1997, membuat banyak usaha batik di Pijenan collapse (runtuh). Usaha-usaha batik mengalami kebangkrutan. Pengusaha batik yang tadinya berjumlah 37 unit usaha, menyusut menjadi hanya sekitar 3 unit usaha. Salah satu usaha batik yang bisa bertahan dari krismon adalah batik TOPO. Walaupun berhasil bertahan, batik TOPO tetap harus mengurangi jumlah karyawannya yang pada waktu itu berjumlah 23 orang. Setelah 4 bulan terkena imbas krismon, batik TOPO berhasil meneruskan usahanya kembali dengan sekitar 15 karyawan.

Batik TOPO mempunyai pegawai sekitar 25 orang yang berdiri pada tahun 1981. Usaha batik TOPO sudah berdiri selama 29 tahun, melewati berbagai peristiwa seperti krisis moneter dan gempa bantul 2006. Pada saat gempa, usaha batik TOPO tidak mengalami musibah yang berarti, tetapi memberikan bantuan untuk penduduk sekitar yang mengalami musibah gempa.

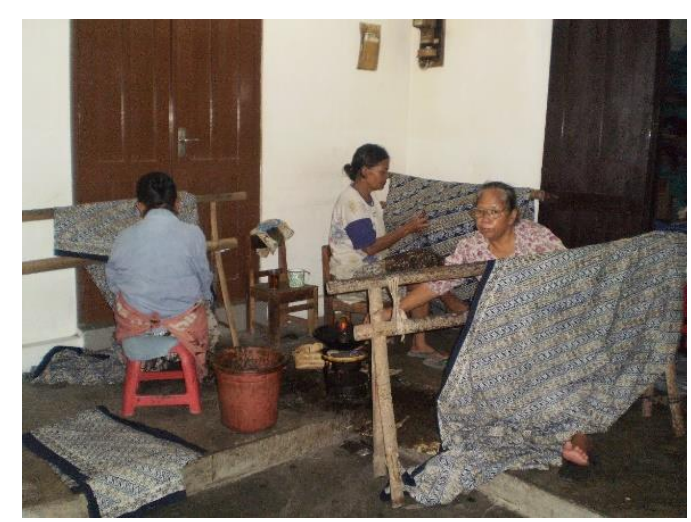

Gambar 3. Beberapa Pegawai Batik TOPO sedang membatik.

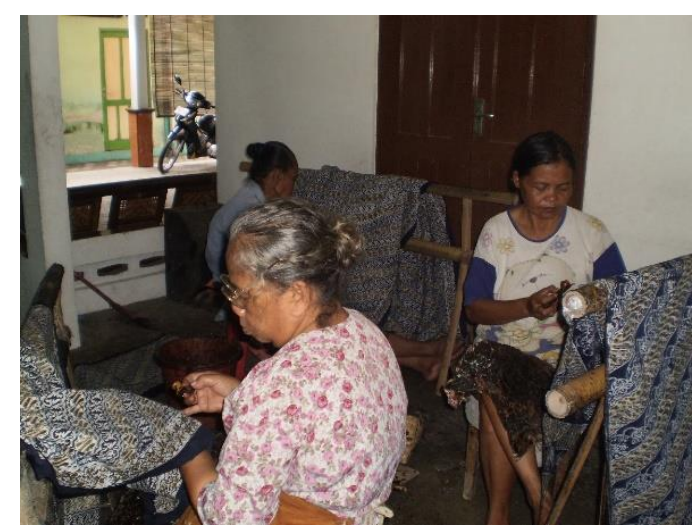

Gambar 4. Suasana Pembatikan di Batik TOPO.

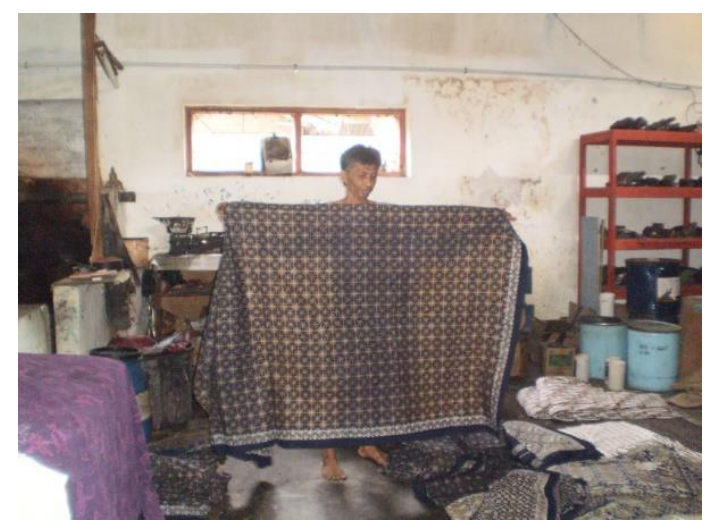

Gambar 5. Tempat Pencelupan dan Pengecapan Batik TOPO.

Karyawan batik TOPO berasal dari wilayah Bantul dan sekitarnya. Walaupun memiliki beberapa karyawan, Bapak Topo masih mengerjakan pesanan batik cap dari konsumennya. Membatik seperti sudah menjadi bagian yang tidak terpisahkan dari kehidupannya. Topo HP membatik dengan 
rasa. Rasa adalah daya penggerak tingkah laku dan kreatifitasnya (M. Dwi Marianto, 2006:41). Topo HP menerima pesanan batik cap dan mempunyai peralatan cap yang sudah dimiliki bertahun-tahun lamanya.

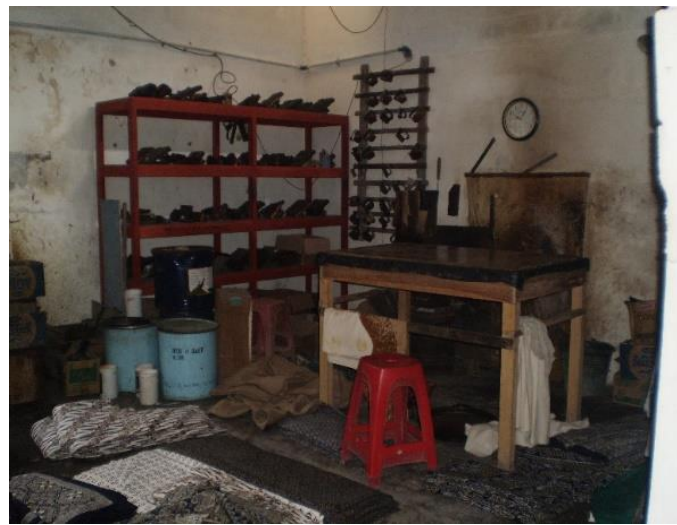

Gambar 6. Beberapa Cap Batik Koleksi Batik TOPO dan Ruang Kerja Topo HP.

Cap Batik TOPO mempunyai ciri khas tersendiri. Ciri khas batik capnya mempunyai corak daerah Bantul. Coraknya ini dinamakan Batik Bantulan. Batik Bantulan mempunyai corak beraneka ragam, yaitu wahyu tumurun, gringsing, cepot, nitik, klithik, liris, galaran dan kawung. Batik Topo hanya membuat batik asli, yaitu batik tulis dan cap. Batik-batik buatan mereka ada yang diwujudkan dalam bentuk tas, sandal batik dan pakaian. Ada juga yang dibuat kain panjang dengan ukuran 2 meter $\times 115$ centimeter, atau selendang. Produk batik TOPO dijual dari harga Rp. 10.000,- sampai Rp. $350.000,-$.

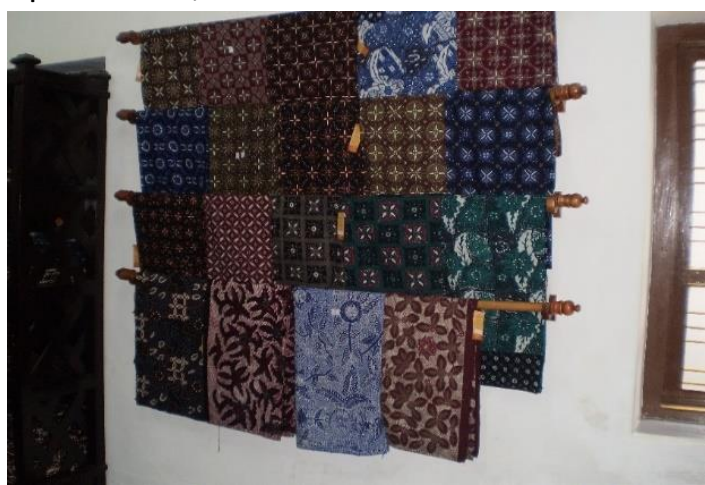

Gambar 7. Koleksi produk-produk kain Batik TOPO Bantul.

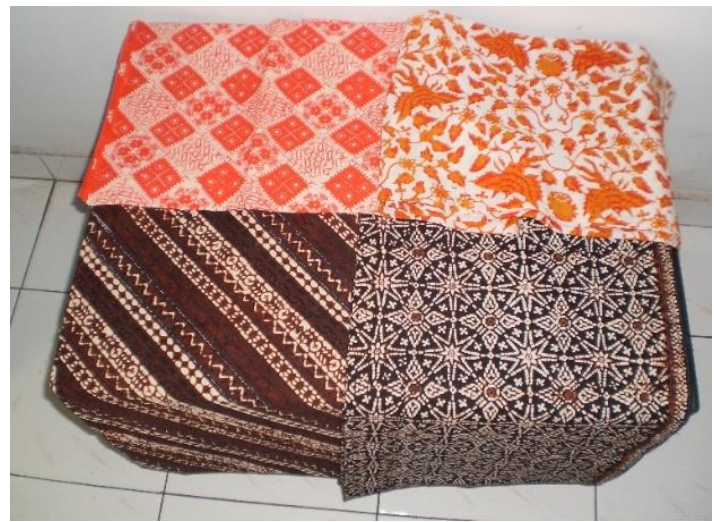

Gambar 8. Koleksi produk-produk kain Batik TOPO Bantul

Bahan dan Peralatan Produksi Batik Tulis dan Cap

Teknik pembuatan batik TOPO Bantul menggunakan teknik batik tulis dan cap. Teknik tersebut mempunyai bahan dan peralatan yang berbeda. Batik tulis menggunakan canting dan batik cap menggunakan alat cap batik. Walaupun demikian, beberapa bahan yang digunakan relatif sama seperti bahan kain dan lilin batik.

Batik TOPO menggunakan beberapa jenis kain untuk proses pembatikan. Bahan kain itu meliputi kain katun dan sutera. Kain katun ada beberapa jenis, yaitu katun primissima, prima, doby dan berkolin. Bahan sutera juga terdiri dari beberapa jenis, yaitu sutera super, kristal, salur dan polos.

Lilin atau malam adalah bahan yang dipergunakan untuk membatik. Lilin batik pada dasarnya ada dua macam yaitu lilin atau malam dan parafin. Lilin atau malam digunakan untuk membuat motif batik, sedangkan parafin digunakan untuk menghasilkan effect pewarnaan yang lebih dramatis. 

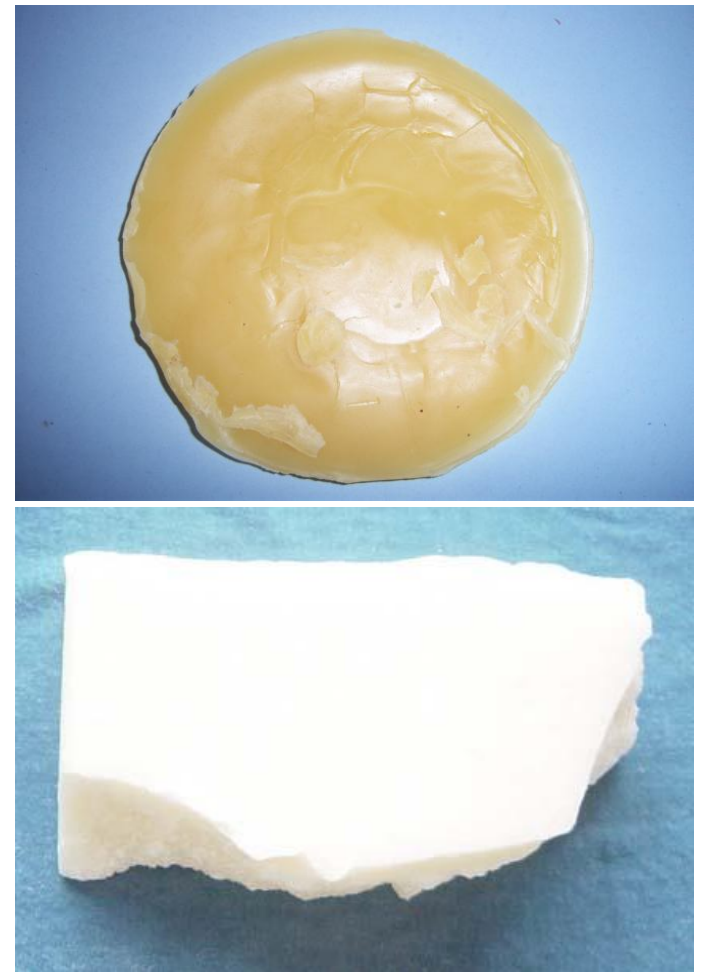

Gambar 9. Lilin/ Malam dan Parafin.

Bahan pewarna untuk pembatikan ada bermacam-macam jenisnya. Jenis pewarna batik yaitu indigosol, rapid, naphtol dan warna alami. Bahan lainnya dalam pembatikan adalah kompor dan wajan batik.

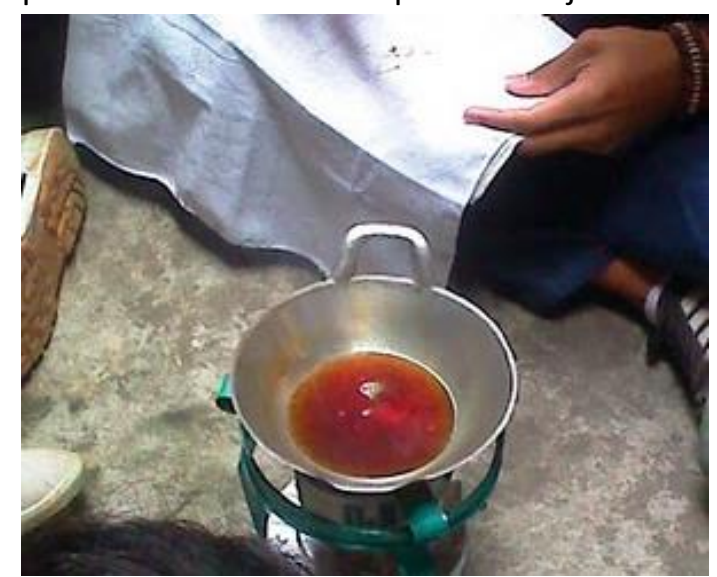

Gambar 10. Kompor dan Wajan.

\section{Proses Pembuatan Batik Tulis dan Cap}

Batik tulis ialah batik yang dihasilkan dengan cara menggunakan canting sebagai alat Bantu dalam melekatkan cairan malam pada kain (Biranul Anas, 1997: 14). Canting adalah alat utama batik tulis terbuat dari tembaga ringan, mudah dilenturkan, tipis namun kuat dipasangkan pada gagang buluh bambu yang ramping. Bagian tembaga yang berbentuk teko kecil merupakan tempat penampungan cairan malam dan corong berlubang yang terdapat pada teko merupakan tempat mengalirnya cairan malam.

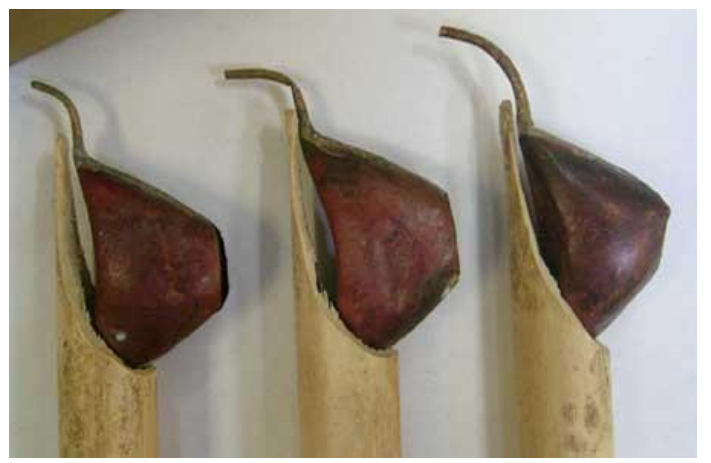

Gambar 11. Canting.

Batik cap ialah batik dengan menggunakan alat berupa canting cap, menggantikan canting tulis. Penggunaan canting cap ini mempermudah pembuatan motif secara berulang-ulang. Cap dibuat dari lempengan tembaga yang membentuk corak pada salah satu permukaannya. Prinsip kerja canting cap sama dengan stempel, hanya perbedaannya terletak pada bahan yang dicapkan.

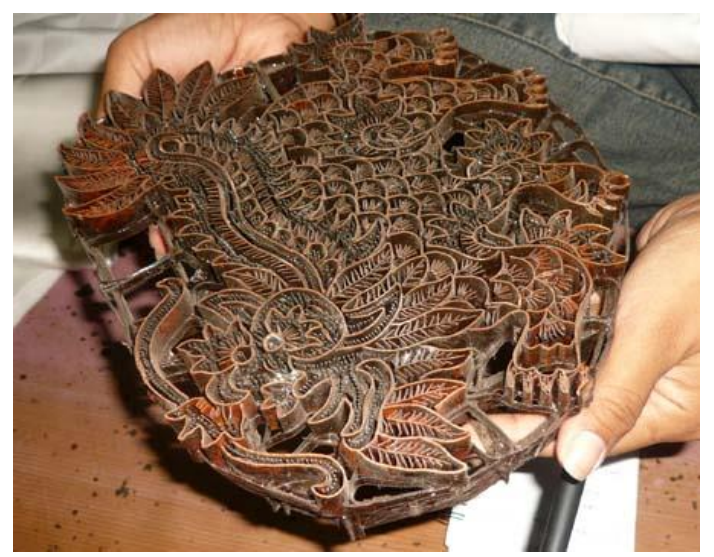




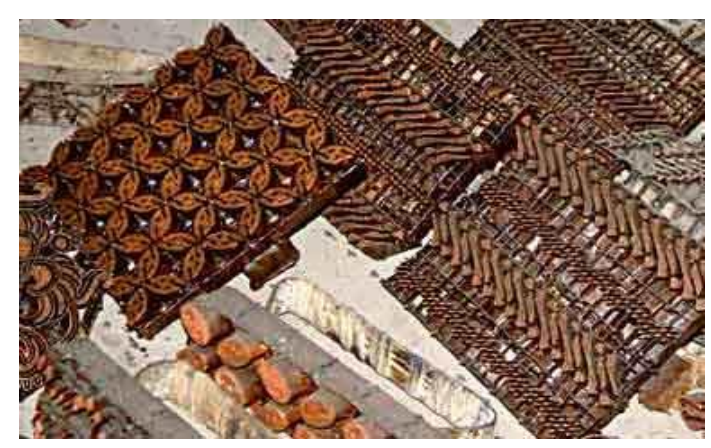

Gambar 12. Alat Cap batik.

Membatik, baik itu batik tulis maupun cap, melalui empat tahap proses pembatikan. Tahap-tahap tersebut adalah tahap persiapan, pembatikan, pewarnaan dan penghilangan warna. Tahap persiapan dimulai dengan pencucian bahan kain dengan air. Fungsinya adalah untuk menghilangkan lapisan tepung kanji yang biasanya terdapat dalam bahan kain. Lapisan tepung kanji yang telah hilang ini membuat kain lebih lentur dan luwes untuk dibatik Proses pencucian bahan kain batik dinamakan dengan nggirah (Sewan Susanto, 1973:6).

Tahap selanjutnya adalah pembatikan. Tahap pembatikan adalah proses penggambaran corak dengan menggunakan canting cap atau canting tulis untuk menorehkan malam pada kain. Proses penggambaran corak ini biasanya mengikuti disain motif pada kain. Bahan kain digambar menggunakan pensil dulu, selanjutnya dibatik.

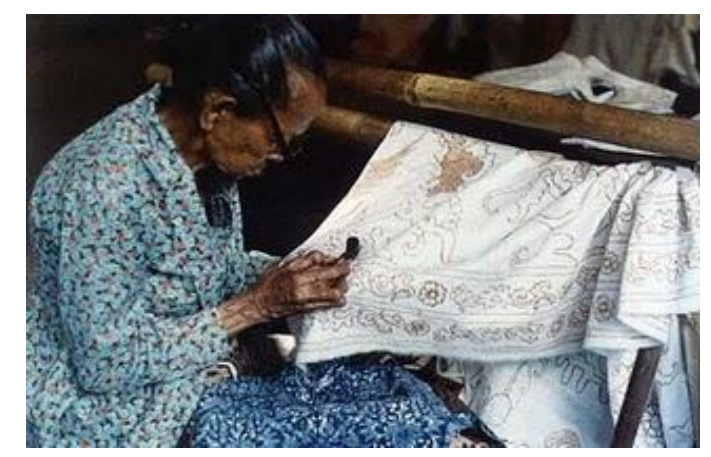

Gambar 13. Pengerjaan Batik Tulis.
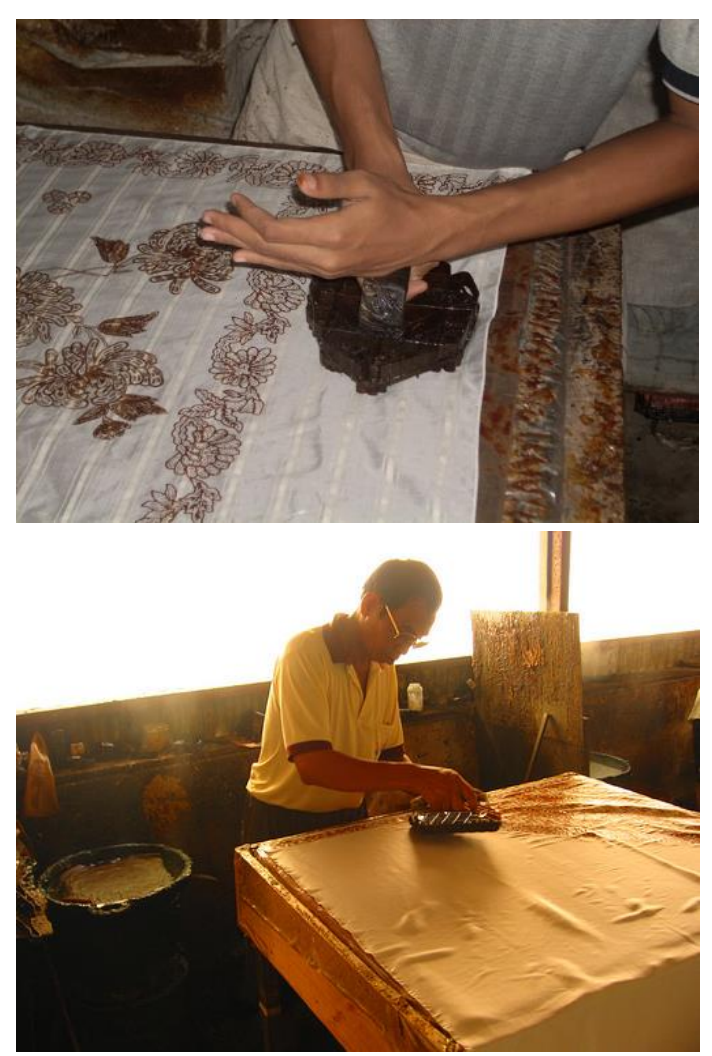

Gambar 14. Pengerjaan Batik Cap.

Proses pewarnaan dilakukan setelah pembatikan. Proses pewarnaan dibedakan menjadi dua macam yaitu pencelupan dan pencoletan. Proses pencelupan adalah kain yang telah dibatik dengan lilin dimasukkan ke dalam air dengan bahan pewarna. Proses pencoletan adalah pewarnaan dengan menggunakan media kuas atau sikat untuk menorehkan bahan pewarna pada kain batik. Proses pencelupan dan pencoletan dapat dilakukan berulangkali untuk mendapatkan warna yang maksimal.

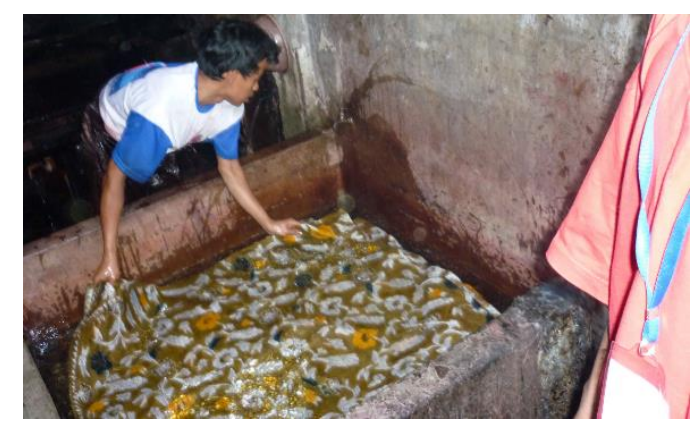

Gambar 15. Proses Pewarnaan. 
Tahap penghilangan lilin dinamakan juga dengan nglorot. Prosesnya adalah dengan cara merendam kain ke dalam air mendidih yang telah dicampur dengan kanji atau soda abu. Fungsinya untuk melepaskan lilin dari kain batik. Kain batik yang telah bersih dari lilin kemudian dijemur dengan cara diangin-anginkan.

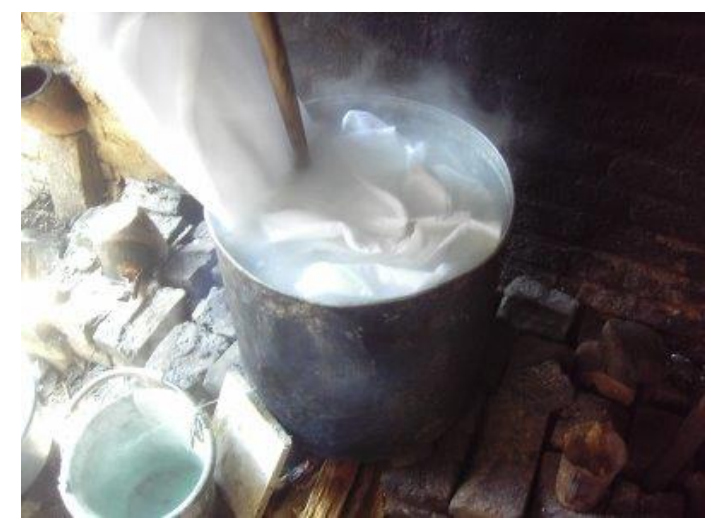

Gambar 16. Pengerjaan Nglorot.

Batik TOPO menggunakan tahaptahap proses pembatikan tersebut. Produksi Batik TOPO juga menggunakan proses pewarnaan pencelupan dan pencoletan. Proses pewarnaan pencoletan digunakan untuk mewarnai bagian-bagian disain batik secara mendetil, yang tidak dapat dicapai dengan proses pewarnaan pencelupan. Selain itu, penggunaan kedua proses ini dapat menambah variasi pewarnaan.

\section{PENUTUP}

Batik adalah world heritage atau warisan dunia. Pengukuhannya dilakukan di Abu Dhabi pada tanggal 2 Oktober 2009. Pengukuhannya sebagai world heritage tentunya membawa dampak positif maupun negatif. Dampak positifnya adalah dunia mengetahui bahwa batik berasal dari Indonesia. Dampak negatifnya adalah banyak negara yang mulai menggunakan batik dan memproses batik secara masal.
Proses batik yang relatif rumit dibuat menjadi lebih sederhana dengan menggunakan alat cetak kain sehingga muncul istilah batik printing. Batik printing adalah sejenis tekstil yang menggunakan motif batik tanpa melalui proses pembatikan. Batik printing terbuat dari beraneka ragam motif batik dengan tekstur kain bermacam-macam bahkan bukan kain katun. Keberadaan batik printing sangat mengkhawatirkan bagi perkembangan batik asli. Selain harganya sangat murah, tekstur kainnya pun sangat beragam. Beberapa pengrajin batik di Indonesia banyak yang beralih memasarkan batik printing. Peralihan ini didukung dengan alasan ekonomis. Dilihat dari segi ekonomis, penjualan batik printing memang lebih menguntungkan. Tetapi, peralihan ini berakibat fatal bagi perkembangan dan pelestarian batik asli, yaitu: batik tulis dan batik cap.

Batik TOPO adalah salah satu usaha lokal yang mencoba untuk melestarikan keberadaan batik asli. Proses pembuatan batik asli yang rumit dan menelan biaya banyak bukan halangan bagi batik TOPO untuk tetap mempertahankan visinya. Bapak Topo selaku pemilik usaha pernah mengatakan " jika bukan kita yang melestarikan batik asli, lalu siapa lagi?". Suatu pernyataan yang lugas tapi bisa berarti sangat inspiratif. Pernyataan itu seperti metafor. Metafor atau metafora mempunyai pengertian mengenai adanya satu produk aktifitas mental kreatif yang selalu muncul. Manakala orang dihadapkan dengan fenomena baru, atau ketika ia sedang bersinggungan dengan peristiwa kultural yang begitu menyentuh, atau genting yang merangsang dia untuk mengartikulturasikan (M. Dwi Marianto, 2010:4). 
Sebagai world heritage, hanya batik asli dengan proses pembatikan melalui canting dan cap yang diakui oleh dunia. Ini berarti hanya batik tulis dan cap yang diakui sebagai world heritage. Batik TOPO tetap konsisten membuat batik tulis dan cap semata-mata supaya batik asli tidak mati dan tetap lestari. Batik merupakan produk kearifan lokal dan warisan budaya bangsa. Keberadaan batik sebagai produk kearifan lokal dan warisan budaya bangsa harus selalu dipelihara perkembangan dan kelestariannya.

\section{KEPUSTAKAAN}

Anas, Biranul. 1997. Indonesia Indah buku yang ke 8 " Batik". Jakarta: Yayasan Harapan Kita/ BP 3 Taman Mini Indonesia Indah.

Haryono, Timbul. 2008. Seni Pertunjukkan dan Seni Rupa dalam Dimensi Bentuk, Ruang, dan Waktu. Surakarta: ISI Press Solo.

Kodiran. 1998. Akulturasi sebagai Mekanisme Perubahan Kebudayaan. Yogyakarta: Majalah Humaniora.

Marianto, M. Dwi. 2006. Quantum Seni. Semarang: Penerbit Dahara Prize.

Marianto, M. Dwi. 2010. Relasi Antara Seni dan Metafora. Yogyakarta: Fotocopi Bahan Kuliah Kritik Seni Rupa.

Suyanto, A. N. 2002. Sejarah Batik Yogyakarta. Yogyakarta: Rumah Penerbitan Merapi.

Susanto, Sewan. 1973. Seni Kerajinan Batik Indonesia. Yogyakarta: Balai Penelitian Batik dan Kerajinan. 